\title{
ON THE TEMPERATURE RESPONSE IN IGE SHEETS TO RADIOACTIVE WASTE DEPOSITS
}

\author{
By K. Philberth \\ (Peter-Rosegger-Strasse 6, D 803 I Puchheim, West Germany)
}

\begin{abstract}
Disposal of the the radioactive waste from the peaceful use of nuclear energy in the central region of the ice sheet of Greenland or Antarctica has been proposed. This paper demonstrates that an area of only $100 \mathrm{~km}^{2}$ on the ice divide is sufficient to dispose of the high-level waste of the whole world for the next 30 years without hazard. The thermal power of the radioactive decay makes the waste containers melt down to a depth of $2 \mathrm{~km}$. Thus the total disintegration heat is spread through a volume of $100 \mathrm{~km}^{2} \times 2 \mathrm{~km}^{2}$. The mean temperature increase in this volume is a few degrees. The temperature increase does not influence the rheology of the ice sheet at any time: for a few ten-thousand years after the dumping the area concerned is too small; later the temperature increase is too small.

RÉsumé. Sur l'augmentation de température dans des calottes glaciaires par le stockage des déchets radioactives. On a proposé le stockage des déchets atomiques de l'usage pacifique de l'énergie nucléaire dans la région centrale de la calotte glaciaire Groenlandaise ou Antarctique. Ici, on explique qu'une region de seulement $100 \mathrm{~km}^{2}$ au sommet de la calotte située est bien suffisante pour déposer les déchets de forte activité du monde entier pour la prochaine trentaine d'années. La puissance thermique de la desintegration radioactive fait enfoncer les containers jusqu'à la profondeur de $2 \mathrm{~km}$. De cette façon, la chaleur totale est diffusée par une volume de $100 \mathrm{~km}^{2} \times 2 \mathrm{~km}$. L'augmentation moyenne de température dans cette volume est quelques degrés. Cette augmentation de température ne change la rhéologie de la calotte à aucun moment; parce que la région influencée est trop petite pendant quelques dix milles années, et plus tard parce que l'augmentation de température est trop petite.

Zusammenfassung. Uber die Temperaturänderung in Eisschilden infolge der Ablagerung von radioaktiven Abfallstoffen. Es besteht der Vorschlag, radioaktive Abfallstoffe aus der friedlichen Nutzung der Kernenergie in den Zentralgebieten Grönlands oder der Antarktis abzulagern. In dieser Arbeit wird gezeigt, dass ein Gebiet von nur $100 \mathrm{~km}^{2}$ am Scheitel des Eisschildes für eine gefahrlose Ablagerung des hochgradigen Abfalls der ganzen Welt innerhalb der nächsten 30 Jahre ausreicht. Die thermische Energie des radioaktiven Abfalls lässt die Behälter in eine Tiefe von $2 \mathrm{~km}$ hinabsinken. Die gesamte Zerfallswärme wird so auf ein Volumen von I $00 \mathrm{~km}^{2} \times 2 \mathrm{~km}$ verteilt. Die mittlere Temperatur in diesem Volumen steigt um wenige Grad. Der Temperaturanstieg beeinflusst die rheologischen Verhältnisse des Eisschildes in keiner Phase: bis zu wenigen Io ooo Jahren nach der Ablagerung ist das betroffene Gebiet zu klein; später ist der Temperaturanstieg zu gering.
\end{abstract}

\section{INTRODUCTION}

In the coming decades it is assumed that nuclear power derived from the fission of uranium and thorium will become the basic energy supply. International co-operation will be necessary to make "atoms for peace" a world-wide benefit and to eliminate its dangers. One serious hazard is the radioactive fission products. Their processing yields high-level waste which usually has an activity of hundreds to thousands of curies per litre. In A.D. 2000 the activity of the world's high-level waste is estimated to be in the order of $1 \mathrm{O}^{12} \mathrm{Ci}$. The ultimate disposal of this waste must be absolutely reliable. B. Philberth has proposed using one of the two large ice sheets as an international dumping place for high-level wastes (Philberth, B., I956, I958, r 959[a], [b], I96o, I96ı; Haefeli, I959, I96r[a], [b], [c]). In recent years there has been renewed interest in this idea (Zeller and others, 1973; Weertman and others, 1973; Weertman, in press).

Should mankind produce radioactive waste at all, and should such radioactive waste be disposed of in the ice sheets? Dealing with waste disposal problems has nothing to do with promoting the use of nuclear energy. Unfortunately, mankind has entered the "nuclear age" without having solved the basic problem of waste disposal. Year by year increasing amounts of waste are produced - in spite of the warning of many scientists and idealists - and we have to provide an international solution for the ultimate disposal of waste as pointed out by E. J. Zeller, D. F. Saunders and E. E. Angino (Weertman and others, 1973, p. 54).

Some people oppose waste disposal in one of the large ice sheets just because they want 
these areas to stay undisturbed. Such a "put-it-anywhere-else" standpoint is not an adequate way to treat one of mankind's gravest problems. On the other hand, the disposal can be limited to a relatively small area of the ice sheet (see below). The disposal problem is urgent. We must not lose time by concentrating the research programs on just one or two methods which now seem to be good and which could turn out to be unreliable after one decade's studies. Every reasonable possibility has to be examined in detail and the results have to be compared. Then a decision can be made on which is the method in which mankind will put its trust. "Considering the flaws in the other disposal schemes that have been suggested, the Antarctic alternative may well prove to be the least of the evils" as W. F. Weeks has said (Weertman and others, I973, p. 54-55).

Concerning waste disposal in one of the large ice sheets, there are two important differences between the scheme of B. Philberth and that of Zeller and others: B. Philberth (1956, I959[b], I96I) has proposed keeping the waste containers well under the surface of the ice sheet but far above the bedrock and had proposed relying on a minimum containment period of $\mathrm{I}$ ooo years or so. Zeller and others (I973), however, consider the possibility that the waste containers will melt down to the bedrock. They allow the waste to contain a considerable portion of ${ }^{239} \mathrm{Pu}$ and rely on a containment period of at least $25^{\circ} 000$ years. Both alterations could be hazardous. Waste containers at the bottom or near to it increase the temperature of near-bottom ice layers and could make the ice sheet slide over its bed; thus the containers at the bottom could be pulverized and contaminated melt water flowing out from beneath the ice sheet could reach the open environment (Weertman and others, 1973, p. 2-3). Catastrophic climatic changes could melt away the ice sheets within some thousands of years (Weertman, 1964), that means before the ${ }^{239} \mathrm{Pu}$ has decayed.

Thermal calculations on waste disposal in the ice sheets usually admit a disposal area of the order of 10000 to $100000 \mathrm{~km}^{2}$. From various points of view, however, the use of such a tremendous area is not welcome. This paper will demonstrate that the world's high-level waste produced from now until even beyond A.D. 2000 can be dumped continually at the divide of one of these ice sheets in an area of not more than $100 \mathrm{~km}^{2}$, i.e. less than $10^{-5}$ times the Antarctic, and about $5 \times 10^{-5}$ times the Greenland, ice surface, without noticeable consequences for the budget, the movement, or the surface conditions of the ice sheet.

The nuclear energy residing in the fission products immediately after fission is roughly $5 \%$ of the total energy released in the fission process. The initial decay of these fission products to inactive material is rapid. Therefore, it is practical to store high-level waste for some years in supervised underground tanks with artificial cooling. Thus the residual energy of the waste for ultimate disposal is reduced to about one-thousandth of the fission energy.

The following calculations will be based on the assumption that the residual energy of all the ultimately disposed waste is $2 \times 10^{18} \mathrm{~W} \mathrm{~s}=6 \times 10^{10} \mathrm{~W}$ years. This is a realistic value for the world's high-level waste within the next decades. Referred to several years' prestored waste, it corresponds to an electric power output from nuclear fission of $10^{12} \mathrm{~W}$ for a period of 30 years. Waste with $2 \times 10^{18} \mathrm{~W}$ s can be disposed of within the area of $100 \mathrm{~km}^{2}$.

At the Greenland ice divide the temperature of the upper $2 \mathrm{~km}$ is nearly constant. These $2 \mathrm{~km}$ multiplied by the area of $100 \mathrm{~km}^{2}$ is an ice volume of $2 \times 10^{11} \mathrm{~m}^{3}$ with a heat capacity of $4 \times 10^{17} \mathrm{~W} \mathrm{~s} / \mathrm{deg}$. The $2 \times 10^{18} \mathrm{~W} \mathrm{~s}$ increase the average temperature of this ice volume by $5 \mathrm{deg}$. This is less than one-fifth of the negative temperature of the upper part in Greenland $\left(-30^{\circ} \mathrm{C}\right)$ and Antarctica $\left(<-50^{\circ} \mathrm{C}\right)$. That means that the homogeneous distribution of the total waste on $100 \mathrm{~km}^{2}$ in a depth range between $20 \mathrm{~m}$ and $2 \mathrm{~km}$ produces only a relatively small temperature increase; $2 \mathrm{~km}$ is two-thirds of Greenland's and half of Antarctica's total ice thickness (cf. sections IV, V, and VI below).

Three thermal problems of this "small-area waste disposal" will be discussed below: the melting down of the waste containers, local overheating and water pockets, and large-scale thermal consequences. 


\section{The Melting Down of the WASTE containers}

There is no problem in introducing the waste into the ice sheet: the waste containers melt themselves down through the ice as long as their thermal power exceeds the heat conduction flux (Philberth, B., I959[a]; Zeller and others, I973). For a stationary I $\mathrm{m}$ diameter sphere with surface temperature of $0^{\circ} \mathrm{C}$ the heat conduction flux in $-30^{\circ} \mathrm{C}$ ice is $400 \mathrm{~W}$. The thermal power of the waste and its variation with time depend on the concentration and the prestorage period. The thermal power of fresh waste decreases in proportion to $t^{-1.2}$, where $t$ is the age; after ten years it decreases exponentially with a half-life of about 30 years. In $-30^{\circ} \mathrm{C}$ ice a container with $500 \mathrm{~kg}$ waste has a melt-down velocity in the order of $100 \mathrm{~m} /$ year for $500 \mathrm{Ci} / \mathrm{l}$, but no movement for $100 \mathrm{Ci} / \mathrm{l}$. Velocities in firn are higher than in ice.

More than half a year after the generation of the fission products, their thermal power is characterized by three isotopes (and their short-lived daughter isotopes): ${ }^{144} \mathrm{Ce},{ }^{\circ} \mathrm{Sr}$ and ${ }^{137} \mathrm{Cs}$ (Philberth, B., I96I). ${ }^{144} \mathrm{Ce}$ has a half-life of 0.8 years, ${ }^{90} \mathrm{Sr}$ and ${ }^{137} \mathrm{Cs}$ together have an average half-life of 30 years; that corresponds to a mean life of 1 year and of 42 years respectively. Therefore, the thermal power of the waste can be calculated as if the total waste consisted of two isotopes only: isotope A with the mean life $\tau=\mathrm{I}$ year and isotope B with the mean life $\sigma=42$ years. The ratio between the thermal power of isotope A to that of isotope B is a function of the time $t$. For $t=0$, that is the moment when the container is put on the ice, let this ratio be called $\alpha /(\mathbf{I}-\alpha)$. The value of $\alpha$ is smaller the longer the pre-storage period.

A good approximation for the melt-down velocity $v$ of a container in ice with constant density and constant temperature is

$$
v=(V+C)[\alpha \exp (-t / \tau)+(\mathrm{I}-\alpha) \exp (-t / \sigma)]-C, \quad v \geqslant 0
$$
where $V$ is the initial velocity (for $t=0$ ) and $C$ is the "heat-loss constant" which depends on
the ice temperature and the form of the container.

If $\alpha \leqslant 0.9$ and if $\sigma / \tau \geqslant 35$ (in fact it is 42$)$ and if $(\mathrm{I}-\alpha)(\mathrm{I}+V / C) \geqslant 4 / 3$, the time $t_{\mathrm{s}}$ after which the container comes to a standstill $(v=0)$ is approximately given by

$$
t_{\mathrm{s}}=\sigma \ln [(\mathrm{I}-\alpha)(\mathrm{I}+V / C)], \quad \text { with } \sigma=42 \text { years. }
$$
Integration of Equation ( $\mathrm{I}$ ) and introduction of $t_{\mathrm{s}}$ from Equation (2) yields the final depth $z_{\mathrm{s}}$
of the containers as

$$
z_{\mathrm{s}}=C \sigma\left[K\left(\mathrm{I}+\frac{\alpha}{\mathrm{I}-\alpha} \frac{\tau}{\sigma}\right)-\mathrm{I}-\ln K\right]
$$
where $K \equiv(\mathrm{I}-\alpha)(\mathrm{I}+V / C)$. Table $\mathrm{I}$ gives $t_{\mathrm{s}}$ and $z_{\mathrm{s}}$ according to Equation (3) for some
realistic values of $\alpha, V$, and $C$.

TABLE I. The MELTING TIME $t_{\mathrm{S}}$ AND THE FINAL DEPTH $z_{\mathrm{S}}$ FOR VARIOUS VAlues OF THE INITIAL FRACTION $\alpha$ OF
THE SHORT-LIVED THERMAL "

$\begin{array}{lccccccccccrr}\alpha & 0.2 & 0.2 & 0.2 & 0.2 & 0.4 & 0.4 & 0.4 & 0.4 & 0.8 & 0.8 & 0.8 & 0.8 \\ V \mathrm{~m} / \mathrm{a} & 50 & 50 & 100 & 100 & 100 & 100 & 150 & 150 & 300 & 300 & 400 & 400 \\ C \mathrm{~m} / \mathrm{a} & 10 & 30 & 10 & 30 & 10 & 30 & 10 & 30 & 10 & 30 & 10 & 30 \\ t_{\mathrm{s} \mathrm{a}} & 66 & 32 & 9 \mathrm{I} & 52 & 79 & 40 & 95 & 54 & 77 & 33 & 88 & 44 \\ z_{\mathrm{s}} \mathrm{km} & 0.95 & 0.49 & 2.38 & 1.57 & 1.60 & 0.86 & 2.73 & 1.73 & 1.67 & 0.78 & 2.47 & 1.37\end{array}$

\section{Local OVERHEATING AND WATER POGKets}

The proposed depth $(2 \mathrm{~km})$ of the field of initial temperature increase and the melt-down data of the containers mentioned are realistic examples, but it is not necessary to keep to these values. Let us consider the extreme case, that all containers are absolutely equal in size, form, and content, and that each of them reaches a depth of say $200 \mathrm{~m}$ in virgin ice at $-30^{\circ} \mathrm{C}$. The concentration of containers in a relatively small depth range causes "overheating" of the ice 
layer concerned and its temperature will approach or reach the melting point. Under these conditions, however, the "heat-loss constant" $C$ becomes very small, and the bulk of containers sinks deeper, thus spreading their heat over a considerable depth range.

The arrival of new containers in such a temperate ice layer produces melt-water pockets which do not refreeze for a long time, but such melt-water pockets are not dangerous even if they should be contaminated with waste: the melt water cannot escape; it is captured between cold ice layers above, below, and to the side. Nevertheless, it is better to avoid such water pockets by using containers which penetrate to a sufficient depth.

If the bedrock is covered by a melt-water layer (Oswald and Robin, 1973) or if the nearbottom ice layer is close to the melting point, all containers should be kept above such a layer, even if the wastes are incorporated in glass or ceramic material. The temperature of deep ice layers could be measured by electric probes of the "wire-pay-out" system (Philberth, K., 1962, 1976[b]; Aamot, 1967, 1968) or by using test containers with radioactive waste of wellknown thermal power, the movement of which is measured by radar pulses.

It is advantageous if the bedrock under the disposal area is frozen to a thickness of at least $100 \mathrm{~m}$. In this case it does not matter if some containers reach the bedrock; for several years or decades there will be a certain amount of melt water around such containers, the area of which has a radius of not more than some metres, while at much larger horizontal distances the virgin temperature of say less than $-5^{\circ} \mathrm{C}$ is maintained. Under these conditions, the heat flux of the container and its melt-water area may unfreeze the bedrock under it to a depth of $5 \mathrm{~m}$ or even $10 \mathrm{~m}$, but it cannot unfreeze its total thickness. Thus the container always remains surrounded by frozen material; at least somewhere in the radius range between io and $100 \mathrm{~m}$ there is cold rock below it and cold ice above it. However, all containers or large clusters of high-energy containers should not reach the bedrock, for the heat flux of many melt-water areas close to each other could locally unfreeze the bedrock throughout its total thickness and force contaminated melt water through fissures.

\section{LARGE-SGALE THERMAL GONSEQUENGES-GENERAL RESUlTS}

With regard to large-scale thermal problems it is unimportant whether or not the waste with its total energy of $2 \times 10^{18} \mathrm{~W}$ s is deposited within 10,30 , or 100 years. But let us calculate with the above-mentioned realistic period of 30 years and with a constant dumping rate. It is useful to study the situation $0-30$ years, $30-300$ years, 3000 , 10 000, 30000 , and 50000 years after the beginning of dumping. For these studies we assume that the present ice sheets will maintain their conditions in a steady state.

The $0-30$ years interval is the dumping period. For example, the total waste is put into three million containers with a net weight of $500 \mathrm{~kg}$ and an initial activity between one million and half a million curies each. That means per year 100 ooo containers with $30 \mathrm{~m}$ horizontal average distance from each other. The initial melt-down velocity in the firn is between $3 \mathrm{~m}$ and $0.5 \mathrm{~m}$ per day, in the ice it is between 400 and $100 \mathrm{~m}$ per year. On its way down through the ice every container releases up to $10^{9} \mathrm{~W} \mathrm{~s} / \mathrm{m}$ as long as its velocity is more than $5^{\circ} \mathrm{m} /$ year. The time constant for the horizontal homogenization of this heat field is some few years only. This time constant being short in relation to the deposition period of 30 years, the temperature field is quasi-homogeneous in the horizontal direction. All three million containers together release in the order of $10^{15} \mathrm{~W} \mathrm{~s} / \mathrm{m}$ in the area of $100 \mathrm{~km}^{2}$. This value corresponds to an ice temperature increase of $5 \mathrm{deg}$. A higher value in one layer means lower values in other layers - the average increase over the whole range between $20 \mathrm{~m}$ and $2 \mathrm{~km}$ depth is $5 \mathrm{deg}$, as calculated initially.

Between $3^{0}$ and 120 years after the beginning of the dumping period the containers freeze in. 200 years after the dumping the thermal power of the waste has become negligible. 300 years after the dumping the original surface is covered with a thick layer of precipitation-in 
Greenland nearly roo $\mathrm{m}$ - a welcome cover for items which did not melt themselves down; the original ice volume with the waste containers has changed its dimensions by some few per cent (Greenland) or per mill (Antarctica).

3 ooo years after the dumping, in Antarctica the deformation of the original ice volume is still less than $5 \%$. In Greenland every vertical length $(\geqslant \mathrm{I} \mathrm{km})$ is reduced to 0.8 of its original value. The original distance of $\mathrm{I}$ ooo $\mathrm{m}$ between the bedrock and the waste-containing ice layer is reduced to $800 \mathrm{~m}$. One-dimensional heat diffusion can be characterized by a "diffusion length" which is equal to $\pi / 2$ multiplied by the square root of the heat diffusivity and of the time. For stationary ice this length is $10 \mathrm{~m}$ multiplied by the square root of the number of years. Between 300 and 3000 years after the dumping, this diffusion length has increased from less than $200 \mathrm{~m}$ to about $600 \mathrm{~m}$ and the bedrock temperature begins to change.

Io ooo years after the dumping, the diffusion length has increased to $\mathrm{I}$ ooo $\mathrm{m}$. In Antarctica the deformations are still not more than $15 \%$. In Greenland, however, the distance between the bedrock and the waste-containing ice layer is reduced to $500 \mathrm{~m}$. The dissipated heat has reached the bedrock and increased its temperature about $2 \mathrm{deg}$.

30 ooo years after the dumping, in Greenland the waste-containing ice layer has reduced its thickness from $2000 \mathrm{~m}$ to about $200 \mathrm{~m}$. Most of the heat has diffused downward into the bedrock and upward against the downward ice movement. The maximum temperature increase is less than I deg.

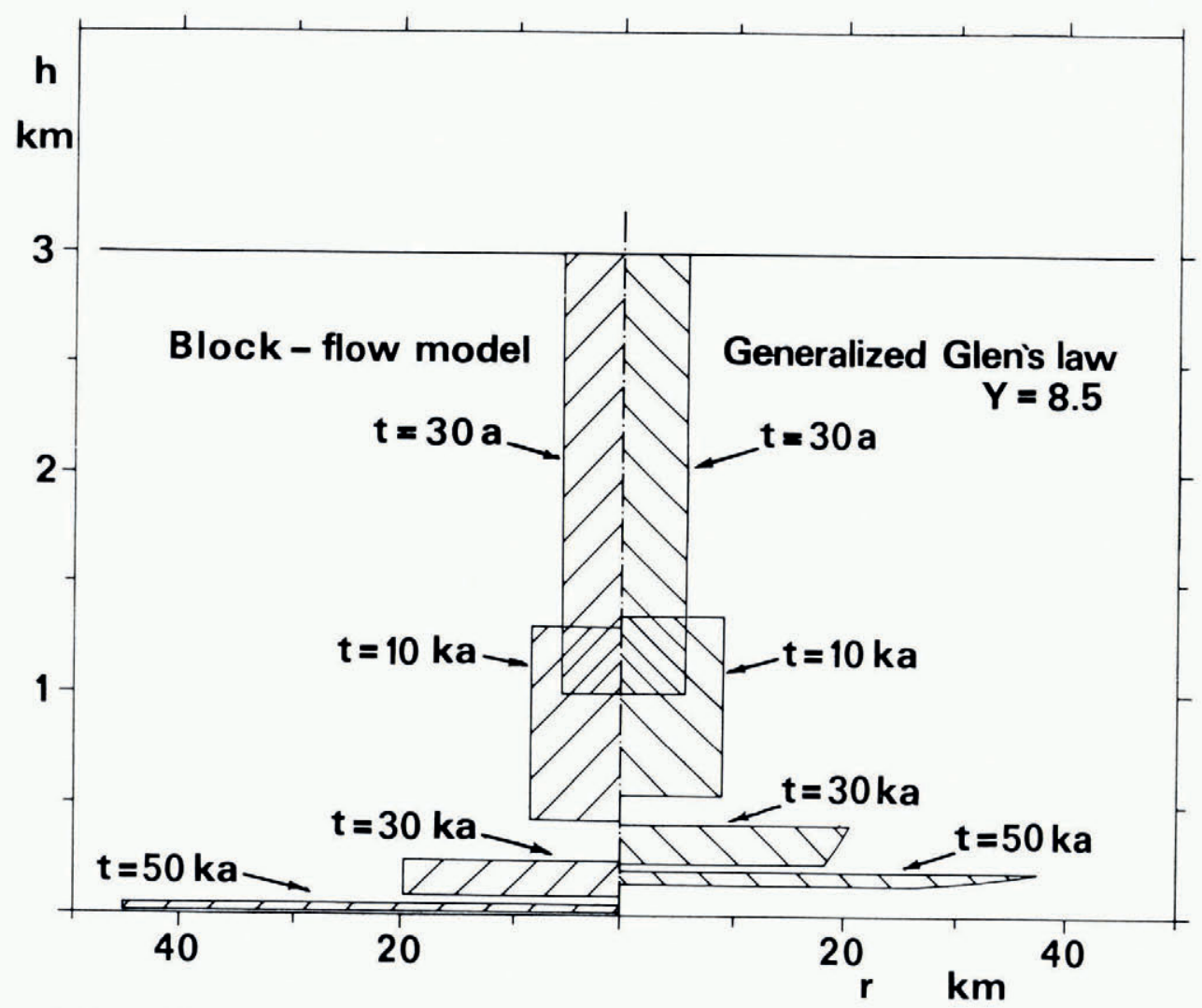

Fig. I. Radius $r$ and height $h$ of a circular deposit volume at different times $t$ for ice flow according to block model (left) and to generalized Glen's law (right). 
50 ooo years after the dumping, in Greenland the waste-containing ice layer has about $50 \mathrm{~m}$ thickness. Nearly all the heat has diffused upwards and downwards, the maximum temperature increase is in the order of $0 . \mathrm{I} \mathrm{deg}$.

\section{LARGE-SGAle thermal CONSEQUENGES-IDEALIZED Gomputations}

The following statements are based on idealized conditions: steady state, horizontal bedrock, constant density and mechanical and thermal properties in the ice volume concerned, approximately constant ice thickness $H$ and accumulation rate $A$ over the area, zero lateral heat diffusion.

Figures $\mathrm{I}, 2,3$ use $H=3 \mathrm{~km}$ and $A=0.25 \mathrm{~m}$ of ice per year; these values are realistic for the Greenland ice divide. The figures are valid for waste with a residual energy of $2 \times 10^{18}$ W s, homogeneously spread at the ice divide or near to it over an area of $100 \mathrm{~km}^{2}$ and a depth of $2 \mathrm{~km}$. Figure I admits rotational symmetry of the ice flow; Figures 2 and 3 admit rotational symmetry, two-dimensionality or any intermediate state between them.

Figure I shows on each side one-half of the cross-sections (striped sections) of a circular deposit ice volume in the beginning $(t=30 \mathrm{a})$ and after 10000,30000 and 50 ooo years: the left side gives radius and height for the block-flow model (horizontal velocity independent of depth); the right side gives radius and height for the much more realistic ice flow according to the generalized Glen's law with the "depth parameter" $Y$ equal to 8.5 (Philberth and Federer, 1971).

Figures 2 and 3 show the temperature increase $\Delta T$ which is caused by the radioactive waste. For the sake of simplicity they are based on the block-flow model and assume that no heat escapes through the upper surface and the lower surface (bedrock). These simplifications distort the result; but to a certain extent the distortions compensate each other.

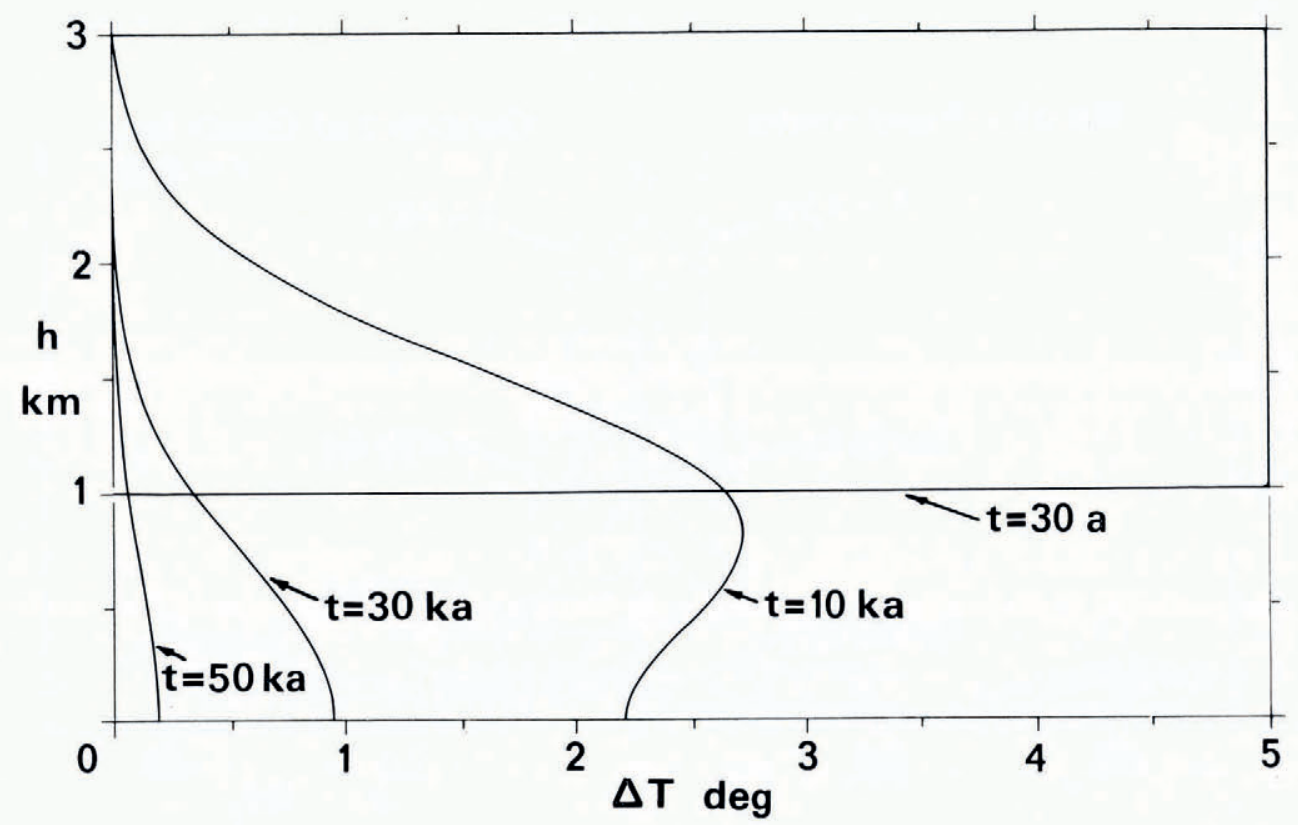

Fig. 2. Profiles of the waste-induced temperature increase $\Delta T$ at different times $t$ for the block-flow model and insulating upper and lower surfaces; $A=0.25 \mathrm{~m}$ of ice/a. 


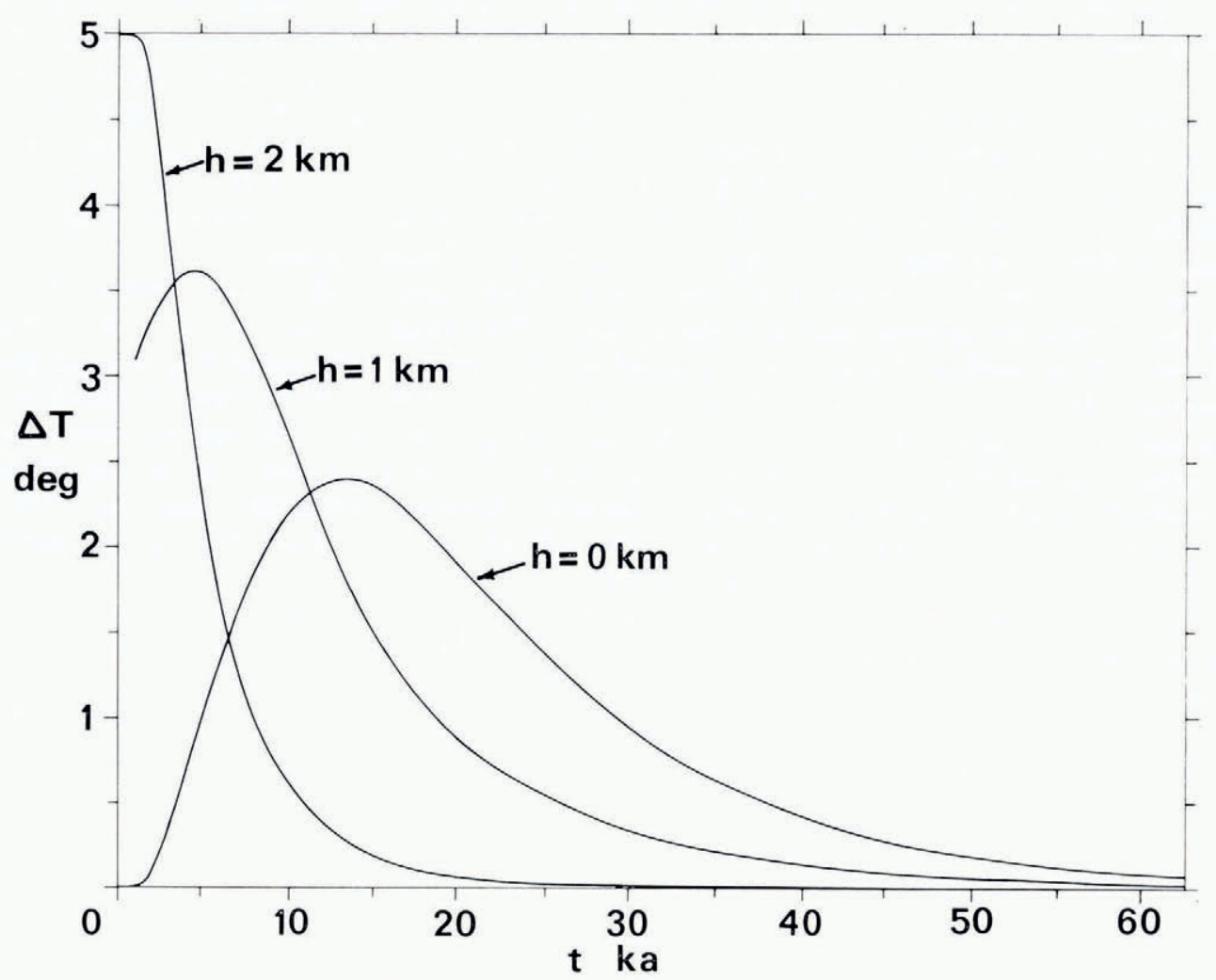

Fig. 3. Waste-induced temperature increase $\Delta T$ versus time $t$ at the heights $h=0, I, 2 \mathrm{~km}$; block-flow model and insulating upper and lower surfaces being assumed; $A=0.25 \mathrm{~m}$ of ice $/ \mathrm{a}, H=3 \mathrm{~km}$.

As long as the melting point is not yet reached, the waste-induced temperature increase $\Delta T$ superimposes itself on the virgin temperature field. The $\Delta T$ values of Figures 2 and 3 result from the equation for one-dimensional heat conduction in a contracting medium (Philberth, K., I972, in press) applied to the Fourier harmonics of the initial $\Delta T$ function. For $t \geqslant 50$ ooo years the temperature increase is described by the equation:

$$
\Delta T=T_{0} \exp (-A t / H) \exp \left(-A h^{2} / 2 H \kappa\right)
$$

where $T_{0}$ is a constant (I I. $\left.8 \mathrm{deg}\right), \kappa$ is the thermal diffusivity $\left(3^{8} \mathrm{~m}^{2} / \mathrm{a}\right)$ and $h$ is the height above the bedrock.

\section{Conclusion}

The disposal of the waste involves a double responsibility: the first is to avoid the escape of radio-active particles even if catastrophic climatic changes or ice surges should cause a rapid decrease of the ice sheet. The second is to avoid risking the stability of the ice sheet or any remarkable change of general conditions.

Radioactive particles can neither migrate to the surface against the accumulation nor downwards through frozen ice layers and/or frozen bedrock (Philberth, B., 196I). It is practically impossible that climatic changes could melt the ice sheet in substantially less than I ooo years (cf. Weertman, I964, and Philberth, K., I976[a]). Such a period is enough for the 
decay of ${ }^{90} \mathrm{Sr},{ }^{137} \mathrm{Cs}$ and even for ${ }^{15} \mathrm{Sm}$ (half-life 80 years, but extremely low energy and percentage), whilst the long-lived fission products are far less dangerous and could even be extracted before the waste is deposited. Glacier surges seem to be caused by increasing temperature of the lower ice layers, with frictional heat causing positive feed-back. Future research is required on how this mechanism works and whether or not the central parts of the large ice sheets are liable to surge. Even extreme surges are quite unlikely to carry the waste containers from the Greenland or Antarctic ice divide to the ocean within less than I ooo years (cf. Weertman and others, I973, p. 3, 53, 54; Weertman, in press).

An increase in the bottom temperature over a large area could-under critical circumstances-lead to widespread sliding of the ice sheet (Weertman and others, 1973; Weertman, in press). Nevertheless, the proposed disposal method excludes the possibility of man-made instability, because the temperature increase after, let us say, 30 ooo years is limited to an area with $20 \mathrm{~km}$ radius (Fig. I). In such a small area around the ice divide, the shear forces are near to zero and a bottom temperature increase of about I deg and a mean temperature increase of about $0.3 \mathrm{deg}$ (Fig. 2) cause no noticeable rheological influence, either direct or by feed-back. 50 ooo years after the dumping, the radius is not more than about $35 \mathrm{~km}$ and the mean temperature increase is less than o. I deg.

These examples are valid for a steady-state ice flow with rotational symmetry and under Greenland conditions. In Antarctica the ice volume containing the waste spreads far more slowly. In the two-dimensional case the initial deposit area should be small (e.g. $2 \mathrm{~km})$ in the direction of the ice flow. In all such cases there is at no time any noticeable impact of the waste disposal on the rheology or the budget of the ice sheet.

\section{REFERENCES}

Aamot, H. W. C. 1967. The Philberth probe for investigating polar ice caps. U.S. Cold Regions Research and Engineering Laboratory. Special Report I 19.

Aamot, H. W. C. 1968. Instrumented probes for deep glacial investigations. Journal of Glaciology, Vol. 7, No. 50, p. $32 \mathrm{I}-28$.

Haefeli, R. 1959. Die internationale glaziologische Grönlandexpedition 1957 bis 1960 (E.G.I.G.). Schweizerische Bauzeitung, Jahrg. 77, Ht. 29, p. 463-68.

Haefeli, R. I96r[a]. Contribution to the movement and the form of ice sheets in the Arctic and Antarctic. Journal of Glaciology, Vol. 3, No. 30, p. 1 $133-5 \mathrm{r}$.

Haefeli, R. I96r[b]. Glaziologische Einführung zur Frage der Beseitigung radioaktiver Abfallstoffe in den grossen Eiskappen der Erde. Schweizerische Zeitschrift für Hydrologie, Vol. 23, Fasc. 1, p. 253-62.

Haefeli, R. Ig6I[c]. Eine Parallele zwischen der Eiskalotte Jungfraujoch und den grossen Eisschildern der Arktis und Antarktis. Geologie und Bauwesen, Jahrg. 26, Ht. 4, p. 191-2 I 3 .

Oswald, G. K. A., and Robin, G. de Q. 1973. Lakes beneath the Antarctic ice sheet. Nature, Vol. 245, No. 5423,

p. $25 \mathrm{I}-54$.
Philberth, B. 1956 . Beseitigung radioaktiver Abfallsubstanzen. Atomkern-Energie (München), I. Jahrg., Ht. I 1-12, p. $396-400$.

Philberth, B. 1958. Disposal of atomic fission products in Greenland or Antarctica. Union Géodésique et Géophysique Internationale. Association Internationale d'Hydrologie Scientifique. Symposium de Chamonix, 16-24 sept. 1958, p. 350.

Philberth, B. I959[a]. Beseitigung radioaktiver Abfallsubstanzen in den Eiskappen der Erde. Atomkern-Energie (München), 4. Jahrg., Ht. 3, p. I $16-19$.

Philberth, B. I959[b]. Stockage des déchets atomiques dans les calottes glaciaires de la Terre. Comptes Rendus Hebdomadaires des Séances de l'Académie des Sciences (Paris), Tom. 248, No. 14, p. 2090-92.

Philberth, B. I960. Discussion of advantages and disadvantages of radioactive waste disposal into geological structures. (In Disposal of radioactive wastes. II. Proceedings of the scientific conference on the disposal of radioactive wastes, ... held at the Oceanographic Museum in the Principality of Monaco, $16-21$ November 1959. Vienna, International Atomic Energy Agency, p. 557.)

Philberth, B. I96I. Beseitigung radioaktiver Abfallsubstanzen in den Eiskappen der Erde. Schweizerische Zeitschrift für Hydrologie, Vol. 23 , Fasc. 1, p. 263-84.

Philberth, K. I 962 . Une méthode pour mesurer les témperatures à l'intérieur d'un inlandsis. Comptes Rendus Hebdomadaires des Séances de l'Académie des Sciences (Paris), Tom. 254, No. 22, p. $388 \mathrm{I}-83$.

Philberth, K. 1972. Factors affecting deep ice temperatures. Nature, Physical Science, Vol. 237, No. 72, p. 44-45.

Philberth, K. I976[a]. Future regard to the atomic waste disposal problem. Journal of Glaciology, Vol. 16, No. 74, p. $277^{-78}$. 
Philberth, K. 1976[b]. The thermal probe deep-drilling method by EGIG in 1968 at station Jarl-Joset, central Greenland. (In Splettstoesser, J. F., ed. Ice-core drilling. Proceedings of a symposium, University of Nebraska, Lincoln, 28-30 August 1974. Lincoln, University of Nebraska Press, p. I I 7-31.)

Philberth, K. In press. Die thermische Tiefbohrung in Station Jarl Joset und ihre theoretische Auswertung. Meddelelser om Gronland.

Philberth, K., and Federer, B. 1971. On the temperature profile and the age profile in the central part of cold ice sheets. Fournal of Glaciology, Vol. 10, No. 58, p. $3^{-1} 4$.

Weertman, J. 1964 . Rate of growth or shrinkage of nonequilibrium ice sheets. Journal of Glaciology, Vol. 5, No. 38 , p. $145-58$.

Weertman, J. In press. Radioactive waste disposal in Antarctica. [Paper presented at Scientific Committee on Antarctic Research meeting, Cambridge, September 1974.]

Weertman, J., and others. 1973. Radioactive wastes on ice. Further discussion, [by] J. Weertman, J. Sibert, W. F. Weeks [and] J. Sternig. Bulletin of the Atomic Scientists, Vol. 29, No. 4, p. 2-3, 53-56. [Includes replies by E. J. Zeller, D. F. Saunders and E. E. Angino; $\mathrm{cf}$. Zeller and others, I 973.]

Zeller, E. J., and others. 1973. Putting radioactive wastes on ice. A proposal for an international radionuclide depository in Antarctica, [by] E. J. Zeller, D. F. Saunders and E. E. Angino. Bulletin of the Atomic Scientists, Vol. 29, No. 1, p. 4-9, 50-52.

\section{DISCUSSION}

G. DE Q. Robin: In September 1974 representatives of the Working Group on Glaciology of the Scientific Committee on Antarctic Research (SCAR), of the International Antarctic Glaciological Project, and the International Commission on Snow and Ice (ICSI) of I.A.H.S. met in Cambridge for one day to consider a request from the Committee on Polar Research of the U.S. Academy of Sciences, for SCAR and ICSI to consider the advisability of dumping nuclear wastes on polar ice sheets. The problem, as put to this group, assumed that it was necessary to isolate the waste from the biosphere for a period of 250 ooo years - ten times the half-life of the highly poisonous ${ }^{239} \mathrm{Pu}$. In this case, the requirements were much more stringent than the case considered by Dr Philberth, who considers that it will be possible to extract such poisonous isotopes with long half-lives before the material is dumped.

The group concluded that the Antarctic ice sheet is not a suitable site for the disposal of radioactive wastes of long half-lives. Their report will be published, but I will mention some of the factors governing their conclusions:

They did not consider that a technology exists that is adequate to recover any dumped waste material if this is necessary due to any failure of dumping systems or other mistakes.

The group considered that it was not practicable to forecast the behaviour of the Antarctic ice sheet for a future period of 250 ooo years - a period much longer than the average duration that any particle of ice remains in the ice sheet. This involves forecasting future climate over this period, which is clearly impracticable. It may be possible to forecast behaviour for some I ooo or even 10 ooo years however.

Another aspect is the difficulty of forecasting when, if at all, future surges of the ice sheet will occur.

A point raised by Dr Philberth's talk is how reliable is the location of the ice divide that he uses as the location of dumping. It appears possible that changes of shape of the ice sheet, for example by shifts of the grounding-floating line of the Antarctic ice sheet due to sea-level changes, may change the location of the ice divide by some tens of kilometres.

I would quote one further conclusion of the group: "We consider that, at this stage, the efforts of the glaciological community should continue to be directed towards a better understanding of the basic physics and thermodynamics of ice sheets. Such an understanding is essential before any profitable consideration can be made of applied problems such as those that would be associated with nuclear waste disposal on ice sheets". 
K. Philberth: Nobody can guarantee the stability of any ice sheet for 250 ooo years. The Cambridge meeting (25 September 1974) refers to Zeller and others (1973) and Weertman and others (1973) in which Zeller and others and Weeks in their turn quote Philberth, B. (I96I). But the latter has never proposed relying on inclusion periods of the order of $\mathrm{r} 00$ ooo years; quite the contrary: Philberth, B. (I96r, p. 266-69) discusses this problem in detail and considers under what conditions an inclusion period of $\mathrm{I}$ ooo years would be sufficient.

A serious contribution to the waste disposal problem should avoid speculations of what could happen in some hundred-thousand years; however, it is necessary to find clear statements as to whether the Antarctic or the Greenland ice sheets can totally melt away in some hundred years. Please compare my contribution to the last afternoon session of the meeting. W. F. BudD: Do you assume that the long-lived wastes such as plutonium can be and would need to be separated from the wastes before disposal of the wastes in the ice sheets?

Philberth: Plutonium 239 and carbon 14, for example, are not fission products. It depends on the reactor type and the processing whether and to what extent they are contained in the waste. The portion of such isotopes in the dumped waste ought to be so small that they cannot seriously contaminate the biosphere, even if the ice sheets should melt completely within some hundred years.

Hot chemistry is developing rapidly and the problem of separating dangerous isotopes is or will be solved. The problem of waste disposal is becoming urgent; we should go ahead with research on its glaciological aspects, and not lose time waiting for the perfection of the hot chemistry. 